\title{
Comparison of Stump Closure Methods in Laparoscopic Appendectomies Performed for Uncomplicated Acute Appendicitis: A Retrospective Cohort Study
}

\author{
Komplike OImayan Akut Apandisitte Uygulanan Laparoskopik Apendektomilerde Güdük \\ Kapatma Yöntemlerinin Karşılaştırılması: Retrospektif Bir Kohort Çalışması
}

\author{
(1) Elvan Onur Kırımker \\ Ankara University Faculty of Medicine, Department of General Surgery, Ankara, Turkey
}

\section{Abstract}

Objectives: Laparoscopic appendectomy offering shorter hospital stay and time to work, less postoperative pain and better cosmesis gained worldwide acceptance and took its place as the standard treatment in the guidelines decades after the first report of laparoscopic appendectomy. In the present study, relationship between stump closure methods and postoperative infectious complications were analyzed.

Materials and Methods: Laparoscopic appendectomy cases performed for non-complicated acute appendicitis at a university hospital in a ten-year period were analyzed retrospectively. Three stump closure methods including stapler, polymer clip and intracorporeal knot were compared.

Results: Totally 391 cases were included in the final analysis. Stapler, polymeric clip and intracorporeal knot were used for closure of the stump in $191(48.8 \%), 52(13.3 \%)$ and $148(37.9 \%)$ patients, respectively. Appendix diameter was found larger in the stapler group and smaller in the intracorporeal knot group. Other preoperative characteristics were similar among the groups. Nine (2.3\%) surgical site infections including 2 intraabdominal abscesses were observed. Eight of 9 surgical site infections were observed in the stapler group with odds ratio of 8,699. Postoperative leucocyte decrease was found to be less frequent and leucocyte decrease was quantitatively less or absent in cases with surgical site infections.

Conclusion: Polymeric clips and intracorporeal knots are the stump closure methods we recommend being preferred over stapler use in cases of uncomplicated acute appendicitis. The course of the peroperative leukocyte count may be valuable in predicting postoperative surgical site infections.

Key Words: Appendicitis, Appendectomy, Laparoscopic Surgery

\section{Öz}

Amaç: Daha kısa hastanede kalış süresi ve daha erken çalışmaya dönüş süresi sunan laparoskopik apendektomi, daha az postoperatif ağrı ve daha iyi kozmesis ile dünya çapında kabul gördü ve ilk laparoskopik apendektomi bildiriminden on yıllar sonra kılavuzlarda standart tedavi olarak yerini aldı. Bu çalışmada güdük kapatma yöntemleri ile postoperatif enfeksiyon komplikasyonları arasındaki ilişki incelenmiştir.

Gereç ve Yöntem: Komplike olmayan akut apandisit nedeniyle 10 yıllık bir süre içinde bir üniversite hastanesinde gerçekleştirilen laparoskopik apendektomi olguları retrospektif olarak incelendi. Stapler, polimer klips ve intrakorporeal dügüm dahil olmak üzere üç güdük kapatma yöntemi karşılaştırıldı.

Bulgular: Nihai analize toplam 391 olgu dahil edildi. Stapler, polimerik klips ve intrakorporeal düğüm sırasıyla 191 (\%48,8), 52 (\%13,3) ve 148 (\%37,9) hastada güdük kapatılması için kullanıldı. Apendiks çapı stapler grubunda daha büyük, intrakorporeal düğüm grubunda daha küçük bulundu. Diğer preoperatif özellikler gruplar arasında benzerdi. İki intraabdominal apse dahil olmak üzere $9(\% 2,3)$ cerrahi alan enfeksiyonu görüldü. Dokuz cerrahi alan enfeksiyonundan 8'i görece risk oranı 8.699 bulunan stapler grubunda gözlendi. Cerrahi alan enfeksiyonu olan olgularda postoperatif lökosit azalması daha az sıklıkta, lökosit azalması ise kantitatif olarak daha az bulundu veya hiç olmadı.

Address for Correspondence/Yazışma Adresi: Elvan Onur Kırımker,

Ankara University Faculty of Medicine, Department of General Surgery, Ankara, Turkey

Phone: +90 5327318075 E-mail: elvanonur_2000@yahoo.com ORCID ID: orcid.org/0000-0002-9890-9540

Received/Geliş Tarihi: 28.01.2021 Accepted/Kabul Tarihi: 03.03.2021

๑Copyright 2021 Ankara University Faculty of Medicine

Journal of Ankara University Faculty of Medicine is published by Galenos Publishing House.

All content are under CC BY-NC-ND license. 
Sonuç: Polimerik klipsler ve intrakorporeal düğümler, komplike olmayan akut apandisit olgularında zımba kullanımına tercih edilmesini önerdiğimiz güdük kapatma yöntemleridir. Peroperatif lökosit sayısının seyri, postoperatif cerrahi alan enfeksiyonlarını öngörmede değerli olabilir.

Anahtar Kelimeler: Apandisit, Apendektomi, Laparoskopik Cerrahi

\section{Introduction}

Multiple treatment options are available in the clinical management of acute appendicitis such as open surgery, laparoscopic surgery, single incision laparoscopic surgery, natural orifice transluminal surgery, endoluminal surgery and non-operative management (1). Laparoscopic appendectomy gained worldwide acceptance and took its place as the standard treatment in the guidelines decades after first report of laparoscopic appendectomy $(2,3)$. Laparoscopy offers shorter hospital stay and time to work, less postoperative pain and better cosmesis (4). Several methods described for both dissection of mesoappendix and closure of appendiceal stump. Each of them was favored in terms of cost, complications and applicability by surgeons. In the present study relationship between closure methods and postoperative infectious complications were analyzed. Since the surgical site infections (SSI) differ between complicated and non-complicated cases, only laparoscopic appendectomies for non-complicated acute appendicitis cases were retrospectively evaluated.

\section{Materials and Methods}

This retrospective study was designed in accordance with Helsinki Declaration and ethical approval was obtained from Local Ethical Committee for Human Studies with the ethics approval ID no. 111-710-20. As a local policy, patients were informed about the procedure and the utilization of anonymized patient data at the time of admission and while taking their consents.

Patients that underwent laparoscopic appendectomy for acute appendicitis between 2010 and 2020 were included into the present study. Complicated appendicitis including perforation or abscess formation those were discovered preoperatively or intraoperatively were excluded. Diagnosis of appendicitis was confirmed with pathology. Perioperative radiology reports of ultrasonic examinations, computed tomography scans and interventions were reviewed. Patient characteristics including age, gender, comorbidities and perioperative laboratory values including complete blood count and C-reactive protein (CRP) levels were obtained from hospital computer database. Operation reports from hospital computer database were inspected and stump closure methods and operation durations were recorded.
Readmission of patients were recorded from hospital database. SSI were retrospectively searched and classified according to SSI classification of American College of Surgeons (5). Firstly, whole study population divided into three main groups according to the method used for appendiceal stump closure specifically laparoscopic cutting linear stapler closure (stapler group), simple intracorporeal ligation of root of appendix (knot group) and closure with polymeric clip (clip group). These three groups were compared in terms of patient and disease characteristics and complications as well. Secondarily two groups with respect to development of SSI were created to evaluate possible risk factors.

\section{Statistical Analysis}

Chi-square test was used to determine relationship between categorical variables whereas t-test was used to compare means. Categorical variables were shown with frequencies and percentages. Continuous variables were shown with mean \pm standard deviation. Mann-Whitney U test was performed when case number of one of compared groups was less than 30 and continuous variables were shown as median \pm interquartile range. Two-sided significance level was chosen as $<0.05$. SPSS 20.0 (IBM Corp, Armonk, US) was used for statistical analysis.

\section{Results}

Totally 399 cases in total with diagnosis of radiologically and clinically non-complicated and histologically proven acute appendicitis were collected. After excluding 8 cases in which two closure methods were used, 391 cases were included in the final analysis. Basic characteristics, laboratory and radiologic results and complications of the whole population of the study were summarized (Table 1). Female gender was constituting $48.3 \%$ of the patients and mean age was found to be $34.3 \pm 13.8$. Preoperative blood CRP levels and leukocyte counts were found to be higher than laboratory ranges as expected. Presence of at least one systemic comorbidity was found to be more frequent in female gender ( $31.7 \%$ vs. $17.3 \%, p=0.001)$ Stapler, polymeric clip and intracorporeal knot were used for closure of the stump in 191 (48.8\%), 52 (13.3\%) and 148 (37.9\%) patients respectively. Patients divided according to stump closure methods used. Each group was compared with the rest of the study population in terms of group characteristics and results. Appendix diameter was found larger in stapler group than in non-stapler group 
$(10.04 \pm 3.12$ vs. $9.05 \pm 2.54, p=0.002)$. Appendix diameter was found smaller in intracorporeal knot group than group of other stump closure methods $(8.95 \pm 2.65$ vs. $9.86 \pm 2.94, p=0.006)$.

\begin{tabular}{ll} 
Table 1: Characteristics and outcomes of whole study cohort \\
$\begin{array}{l}\text { Characteristics } \\
\text { Female }\end{array}$ & $189(48.3 \%)$ \\
\hline Age & $34.31 \pm 13.80(15-78)$ \\
\hline Preoperative CRP (mg/L) & $38.01 \pm 51.91(0.10-348.2)$ \\
\hline Preoperative leukocyte (x109/L) & $12.52 \pm 439(3.05-29.62)$ \\
\hline Appendix diameter (mm) & $9.51 \pm 2.86(4-24)$ \\
\hline Stump closure technique & \\
\hline Stapler & $191(48.8 \%)$ \\
\hline Hemo clip & $52(13.3 \%)$ \\
\hline Intracorporeal knot & $148(37.9 \%)$ \\
\hline Patients having at least one & $95(24.3 \%)$ \\
\hline comorbidity & $66.27 \pm 57.42(0.1-297.3)$ \\
\hline Postoperative day 1 CRP (mg/L) & 10,9403789 \\
\hline Postoperative day 1 leukocyte (x10 $/ \mathrm{L})$ & $54(22.0 \%)$ \\
\hline Postoperatively CRP decreased & $227(65.0 \%)$ \\
\hline Postoperatively leukocyte decreased & $2.36 \pm 1.49(1-10)$ \\
\hline Postoperative hospital stay & $32(8.2 \%)$ \\
\hline Readmission & $7(1.8 \%)$ \\
\hline Superficial wound infection & $2(0.5 \%)$ \\
\hline Deep wound infection & $8(2.0 \%)$ \\
\hline Postoperative ileus & \\
\hline CRP: C-reactive protein & \\
\hline
\end{tabular}

Comparison of polymeric clip with other stump closure methods revealed no significant difference in terms of preoperative characteristics and outcomes (Table 2-4).

Totally 9 (2.3\%) SSI including 2 intrabdominal abscess and 7 superficial incision site infections were detected. Deep SSI was not observed. An analysis was performed to identify risk factors for developing SSI. Cases with and without SSI were compared. Female gender was found to be less frequent in SSI group than non-SSI group ( $p=0.023)$. Preoperative CRP level was found to be higher in SSI group than non-SSI group $(p=0.047)$. Utilization of stapler was found to increase the risk of developing SSI 7.7 times ( $p=0.016$ ). Change in leukocyte count between preoperative count and postoperative first day count was found to be significantly different between groups with and without SSI. Moreover, rate of patients whose leukocyte count was decreased immediately after operation is lower group with SSI (22.2 vs. 66.2, $\mathrm{p}=0.010)$. Other parameters were similar between groups with and without SSI (Table 5). No mortality was seen in the study population during perioperative followup.

\section{Discussion}

Although acute appendicitis has historically been a serious cause of death due to intra-abdominal sepsis, mortality is now mostly a matter of debate limited to complicated appendicitis cases, thanks to diagnostic methods and surgical advances. Common appendectomy complications may include

\section{Table 2: Stapler vs other stump closure methods}

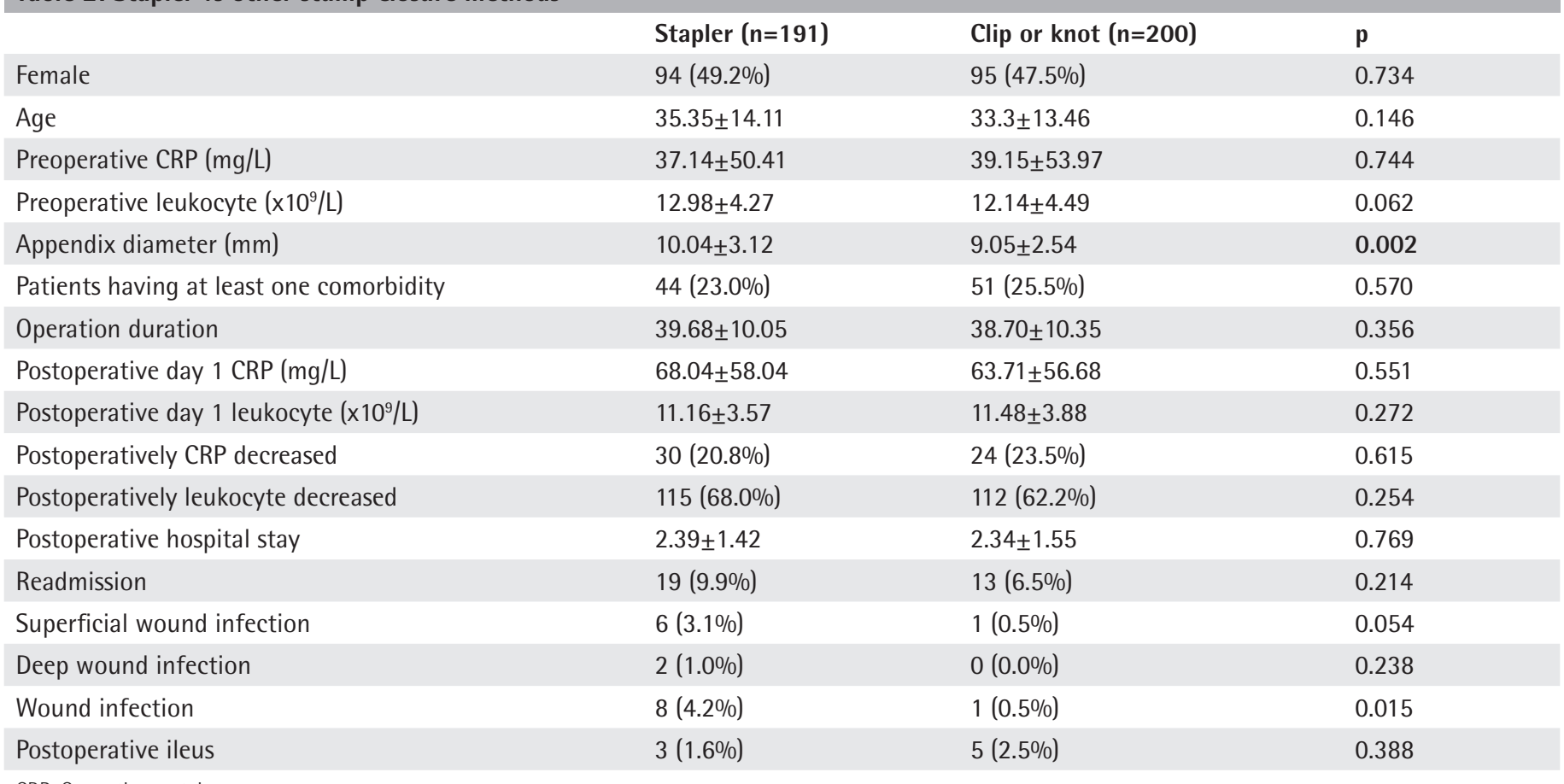


wound infections, postoperative pain and postoperative ileus. Laparoscopy appendectomy is today's standard approach. In an article from 2011 in the United States, it was reported that appendectomy was performed laparoscopically at a rate of $67 \%$ even in complicated cases (6). The visible benefit of laparoscopic appendectomy is that it provides better cosmesis with small incisions. In addition, it has been reported to be advantageous in terms of postoperative pain, quality of life, and incision infections (7). In a meta-analysis comparing laparoscopy and open surgery in perforated appendectomies, although the mortality rate was lower in $L A$, intraabdominal abscess rates were found to be similar. Notwithstanding the fact

Table 3: Intracorporeal knot vs other stump closure methods

\begin{tabular}{|c|c|c|c|}
\hline & Knot $(n=148)$ & Stapler or clip $(n=243)$ & $\mathbf{p}$ \\
\hline Female & $70(47.3 \%)$ & $119(49.0 \%)$ & 0.748 \\
\hline Age & $33.26 \pm 13.61$ & $34.95 \pm 13.91$ & 0.239 \\
\hline Preoperative leukocyte (x109/L) & $11.93 \pm 4.56$ & $12.93 \pm 4.26$ & 0.305 \\
\hline Appendix diameter (mm) & $8.95 \pm 2.65$ & $9.86 \pm 2.94$ & 0.006 \\
\hline Postoperative day 1 CRP (mg/L) & $64.28 \pm 62.45$ & $66.83 \pm 56.11$ & 0.769 \\
\hline Postoperative day 1 leukocyte (x109/L) & $10.43 \pm 4.00$ & $11.23 \pm 3.64$ & 0.054 \\
\hline Postoperatively CRP decreased & $10(18.9 \%)$ & $44(22.8 \%)$ & 0.540 \\
\hline Postoperatively leukocyte decreased & $84(64.1 \%)$ & $143(65.6 \%)$ & 0.780 \\
\hline Deep wound infection & $0(0.0 \%)$ & $2(0.8 \%)$ & 0.528 \\
\hline Wound infection & $1(0.7 \%)$ & $8(3.3 \%)$ & 0.162 \\
\hline Postoperative ileus & $3(2.0 \%)$ & $5(2.1 \%)$ & 0.644 \\
\hline
\end{tabular}

CRP: C-reactive protein

\section{Table 4: Polymeric clip vs. other stump closure methods}

\begin{tabular}{|c|c|c|c|}
\hline & Clip $(n=52)$ & Stapler or knot $(n=339)$ & $\mathbf{p}$ \\
\hline Female & $25(48.1 \%)$ & $164(48.4 \%)$ & 0.968 \\
\hline Age & $33.5 \pm 13.14$ & $34.44 \pm 13.92$ & 0.649 \\
\hline Preoperative leukocyte (x10%/L) & $12.73 \pm 4.27$ & $12.51 \pm 4.42$ & 0.742 \\
\hline Appendix diameter (mm) & $9.31 \pm 2.25$ & $9.55 \pm 2.96$ & 0.593 \\
\hline Operation duration & $40.43 \pm 10.78$ & $39.02 \pm 10.11$ & 0.379 \\
\hline Postoperative day 1 CRP (mg/L) & $63.08 \pm 50.06$ & $67.04 \pm 59.12$ & 0.662 \\
\hline Postoperative day 1 leukocyte (x109/L) & $11.48 \pm 3.88$ & $10.85 \pm 3.77$ & 0.279 \\
\hline Postoperatively CRP decreased & $14(28.6 \%)$ & $10(18.9 \%)$ & 0.248 \\
\hline Postoperatively leukocyte decreased & $28(57.1 \%)$ & $84(64.1 \%)$ & 0.390 \\
\hline Deep wound infection & $0(0.0 \%)$ & $2(0.6 \%)$ & 0.579 \\
\hline Wound infection & $0(0.0 \%)$ & $9(2.7 \%)$ & 0.614 \\
\hline Postoperative ileus & $2(3.8 \%)$ & $6(1.8 \%)$ & 0.289 \\
\hline
\end{tabular}




\begin{tabular}{|c|c|c|c|}
\hline & $\begin{array}{l}\text { Surgical site infection developed } \\
(n=9)\end{array}$ & $\begin{array}{l}\text { No surgical site infection } \\
(n=382)\end{array}$ & $\mathbf{p}$ \\
\hline Female & $1(11.1 \%)$ & $188(49.2 \%)$ & 0.023 \\
\hline Age & $21.5 \pm 9$ & $31 \pm 20$ & 0.245 \\
\hline Preoperative CRP (mg/L) & $49.3 \pm 70.55$ & $18.8 \pm 50.70$ & 0.047 \\
\hline Preoperative leukocyte (x109/L) & $11.62 \pm 6.32$ & $12.16 \pm 6.07$ & 0.242 \\
\hline Patients having at least one comorbidity & $0(0.0 \%)$ & $95(24.9 \%)$ & 0.079 \\
\hline \multicolumn{4}{|l|}{ Stump closure technique } \\
\hline Stapler & $8(88.9 \%)$ & $183(47.9 \%)$ & \multirow[b]{2}{*}{0.016} \\
\hline Clip & 0 & $52(13.6 \%)$ & \\
\hline Postoperative day 1 leukocyte (x109/L) & $12.87 \pm 6.23$ & $10.41 \pm 4.76$ & 0.639 \\
\hline Postoperative leukocyte decrease & $-1.47 \pm 0.54$ & $1.63 \pm 5.34$ & 0.035 \\
\hline Postoperatively CRP decreased & $2(40 \%)$ & $52(21.6 \%)$ & 0.303 \\
\hline Postoperatively leukocyte decreased & $2(22.2 \%)$ & $225(66.2 \%)$ & 0.010 \\
\hline
\end{tabular}

CRP: C-reactive protein

that operation time is longer in LA, the SSI rate was found to be lower and the hospital stay was shorter (8). In laparoscopic appendectomy, the appendix root can be closed with various techniques. We can list these methods as follows: Metal clip, polymeric clip, stapler, endoloop, intracorporeal ligation, purse suture (9). Stapler, polymeric clip and intracorporeal ligation are applied according to the preference of the surgeon in our clinic. Stapler and polymeric clip application are fast methods for surgeons at almost every level of skill and experience, but the ease and duration of intracorporeal ligation of the appendix root may vary depending on the experience and skill of the surgeon. Stapler application usually requires the use of a $12 \mathrm{~mm}$ or $15 \mathrm{~mm}$ diameter port outside the camera port. Endoloop can be easily applied by inserting a commercially available knot loop system into the appendix. Metal clip have a structure that is more prone to dislocation than polymeric clips, and they may not be applied to the root of the appendix with the produced sizes. Among these methods, the cost increase due to stapled medical device is the most prominent. In a systematic analysis, average costs were reported as 153 euro for stapler, 20 euro for polymeric clip and 70 euro for ready endoloop (10). Although the intracorporeal knot method using 1 polyglactin sold for a few euros is not expected to create more cost, cost calculations are not within the scope of this study.

In separate comparisons, it was observed that the diameter of the preoperative appendix was larger in the stapler group compared to other stump closure methods. The reason for such result may be that stapler application is found to be safer and more applicable in cases where the appendix is more inflamed, and the appendix diameter is larger. In cases which appendix is completely became an infected and partially necrotic tissue, firing a stapler onto the caecum base would be the only safe and proper method. It has been reported that the diameter of the appendix base is associated with perforation and gangrene in the histological examination results with more complicated pathologies (11). Although the diameter of the appendix and the number of leukocytes in the polymeric clip applied cases were lower than the stapler group, it was not statistically significant. Since polymeric clip application in appendectomies started later in our clinic, the number of patients in this group is less and hence the difference in the means did not reach the significance level.

Comparing the patients with and without SSI, female patients were observed less frequently among patients with infection. Superficial wound infection was not observed in female patients, however only one deep wound infection has been reported in both sexes. There was no significant difference in the preoperative characteristics of male and female patients, other than the higher frequency of comorbidity in female patients. In the group with wound infection, preoperative CRP level was found to be higher than those without. This may be an indicator of the severity of the disease at the time of application. It has been reported that the preoperative CRP level is a factor that increases the length of hospital stay (12).

It was identified that the stump was closed with stapler in $88.9 \%$ of the cases with SSI when the stump closure 
methods of the two groups examined in terms of SSI and that the stump closure with stapler carries an 8.7-fold risk in terms of SSI compared to closure with other methods. Such result demonstrates a $4.2 \% \mathrm{SSI}$ rate in the stapler group. In a systematic review published in 2009, no significant difference was found between stapler and Endoloop in terms of hospital stay, abscess development, and complication development (13). In another article comparing stapler, polymeric clip and invaginating suture, no significant difference was found between the complications among the 3 methods (9). In another study, endoscopic stapler and polymeric clip were compared for 246 cases, and as a result, no significant difference was found in terms of complications and length of hospital stay (14). In another study comparing endoscopic stapler and polymeric clip, after propensity score matching, no difference was observed between stapler and polymeric clip in terms of complication frequency (15). In a 2017 systematic review, when endoscopic stapler and tying methods were compared, it was reported that endoscopic staples were advantageous in terms of superficial wound infections and postoperative complications compared to ligation, but the two methods were not superior to each other in terms of deep wound infections and hospital stay (16). In our study, larger appendix diameter in patients using staplers may suggest that staples were used in clinically non-complicated but more severe cases. However, no significant difference was found between appendix diameters with respect to the patients who developed postoperative SSI and those who did not.

Although not among the primary results of the study, the number of perioperative leukocytes was found to be associated with the development of SSI. Leukocyte count, which is one of the preoperative inflammatory markers, is expected to decrease with the removal of the focus of infection in the postoperative period. However, this may not occur in every patient. The patients included in the study were grouped according to whether their leukocyte count decreased or not the day after surgery. In addition, the amount of change in the leukocyte count was also calculated. In $66.2 \%$ of the patients who did not develop SSI postoperatively, the leukocyte count decreased by an average of $1.6310^{3} / \mathrm{mm}^{3}$ the next day whereas in $22.2 \%$ of the patients who developed SSI, the leukocyte change was $1.4710^{3} / \mathrm{mm}^{3}$. In the literature review, a report showing the predictive value of leukocytosis for intraabdominal abscess was found (17). Evaluation of these parameters in larger patient populations may be useful for identifying individuals at risk for wound infection after uncomplicated appendectomies and for their close postoperative follow-up. On the other hand, observation of postoperative leukocyte decrease may contribute to the decision of discharge of patients.

It has been reported in several articles that staples are an important cost factor although not included within the scope of this study (18-22). In our country, the purchase prices vary from hospital to hospital and in time, staples have become significantly more expensive. The stapler can facilitate the operation since it allows the user to staple and cut both the mesoappendix and the appendix at the same time. In addition, a stapler can be applied to the non-inflamed cecum wall in cases where the appendix is thick and inflamed. In our case series, only $9(2.3 \%)$ of the SSI count were found. Although the statistical results were significant, it reduced the sharpness of the results. In order to overcome this problem, propensity score matching can be applied in larger series. The absence of wound SSI in polymeric clip application and the low cost of this application made this method attractive.

\section{Conclusion}

Considering their low cost and low SSI rates, polymeric clips and intracorporeal knots are the stump closure methods we recommend to be preferred over stapler use in cases of uncomplicated acute appendicitis. The course of the perioperative leukocyte count may be valuable in predicting postoperative SSI.

Acknowledgement: Author gives thanks to professors Cihangir Akyol, Ayhan Bülent Erkek, Ethem Geçim and Mehmet Ayhan Kuzu for leading contributions into minimally invasive colorectal program of the institute.

\section{Ethics}

Ethics Committee Approval: The study was approved by the Ethics Committee of the Ankara University School of Medicine (approval number: 111-710-20).

Informed Consent: Informed consent was obtained from all participants in the study.

Peer-reviewed: Externally peer-reviewed.

Financial Disclosure: The author declared that this study received no financial support.

\section{References}

1. Wagner M, Tubre DJ, Asensio JA. Evolution and Current Trends in the Management of Acute Appendicitis. Surg Clin North Am. 2018;98:10051023.

2. Di Saverio S, Birindelli A, Kelly MD, et al. WSES Jerusalem guidelines for diagnosis and treatment of acute appendicitis. World J Emerg Surg. 2016;11:34.

3. Semm K. Endoscopic appendectomy. Endoscopy. 1983;15:59-64.

4. Ukai T, Shikata S, Takeda H, et al. Evidence of surgical outcomes fluctuates over time: results from a cumulative meta-analysis of laparoscopic versus open appendectomy for acute appendicitis. BMC Gastroenterol. 2016;16:37.

5. Surgical Site Infection (SSI) Event: Center for Disease Control. 2010.http://www.cdc.gov/nhsn/PDFs/pscManual/9pscSSIcurrent. pdf?agree=yes\&tnext=Accept. Updated January 2021. Accessed January 10, 2021.

6. Masoomi H, Nguyen NT, Dolich MO, et al. Laparoscopic appendectomy trends and outcomes in the United States: data from the Nationwide Inpatient Sample (NIS), 2004-2011. Am Surg. 2014;80:1074-1077. 
7. Gorenoi $V$, Dintsios CM, Schönermark MP, et al. Laparoscopic vs. open appendectomy: systematic review of medical efficacy and health economic analysis. GMS Health Technol Assess. 2007;2:Doc22.

8. Athanasiou C, Lockwood S, Markides GA. Systematic Review and MetaAnalysis of Laparoscopic Versus Open Appendicectomy in Adults with Complicated Appendicitis: an Update of the Literature. World J Surg. 2017;41:3083-3099.

9. Strzałka M, Matyja M, Rembiasz K. Comparison of the results of laparoscopic appendectomies with application of different techniques for closure of the appendicular stump. World J Emerg Surg. 2016;11:4.

10. Knight SR, Ibrahim A, Makaram $N$, et al. The use of polymeric clips in securing the appendiceal stump during laparoscopic appendicectomy: a systematic review. Eur J Trauma Emerg Surg. 2019;45:665-670.

11. Delibegović S, Mehmedović Z. The Influence of the Appendiceal Base Diameter on Appendix Stump Closure in Laparoscopic Appendectomy. World J Surg. 2016;40:2342-2347.

12. Zhang $P$, Zhang $Q$, Zhao $H$, et al. Factors affecting the length of hospital stay after laparoscopic appendectomy: A single center study. PLoS One. 2020;15:e0243575.

13. Sajid MS, Rimple J, Cheek $E$, et al. Use of endo-GIA versus endo-loop for securing the appendicular stump in laparoscopic appendicectomy: a systematic review. Surg Laparosc Endosc Percutan Tech. 2009;19:11-5.

14. Graham CW, Komidar L, Perger L. Comparison of Polymeric Clips and Endoscopic Staplers for Laparoscopic Appendectomy. J Laparoendosc Adv Surg Tech A. 2019;29:240-242.
15. Al-Temimi MH, Berglin MA, Kim EG, et al. Endostapler versus Hem-O-Lok clip to secure the appendiceal stump and mesoappendix during laparoscopic appendectomy. Am J Surg. 2017;214:1143-1148.

16. Mannu GS, Sudul MK, Bettencourt-Silva JH, et al. Closure methods of the appendix stump for complications during laparoscopic appendectomy. Cochrane Database Syst Rev. 2017;11:006437.

17. Dickinson CM, Coppersmith NA, Luks Fl. Early Predictors of Abscess Development after Perforated Pediatric Appendicitis. Surg Infect (Larchmt). 2017; 18:886-889.

18. Sohn $M$, Hoffmann $M$, Pohlen $U$, et al. [Stump closure in laparoscopic appendectomy. Influence of endoloop or linear stapler on patient outcome]. Chirurg. 2014;85:46-50.

19. Delibegović $S$, Mehmedovic Z. The influence of the different forms of appendix base closure on patient outcome in laparoscopic appendectomy: a randomized trial. Surg Endosc. 2018;32:2295-2299.

20. Zorzetti N, Lauro A, Vaccari $S$, et al. A systematic review on the cost evaluation of two different laparoscopic surgical techniques among 996 appendectomies from a single center. Updates Surg. 2020;72:1167-1174.

21. Parikh PP, Tashiro J, Wagenaar AE, et al. Looped suture versus stapler device in pediatric laparoscopic appendectomy: a comparative outcomes and intraoperative cost analysis. J Pediatr Surg. 2018;53:616-619.

22. Escolino M, Becmeur F, Saxena A, et al. Endoloop versus endostapler: what is the best option for appendiceal stump closure in children with complicated appendicitis? Results of a multicentric international survey. Surg Endosc. 2018;32:3570-3575. 